\author{
ZBIGNIEW KARPUS, \\ Nicolaus Copernicus University in Toruń (Toruń, Poland) \\ e-mail: zk@umk.pl, ORCID 0000-0001-5018-976X
}

OLENA HUMENIUK,

Borys Grinchenko Kyiv University (Kyiv, Ukraine)

e-mail:o.gumeniuk85@gmail.com, ORCID 0000-0003-0497-6767

\title{
EDUCATION OF INTERNED SOLDIERS OF UKRAINIAN PEOPLE'S ARMY IN POLAND: THE CASE OF THE CAMP IN ALEKSANDRÓW KUJAWSKI
}

\begin{abstract}
The purpose of the article is to analyze the educational activity - the system of its organization and directions peculiar to the military servants of the Army of the Ukrainian People's Republic (UNR) interned in camps of Poland in the early 1920s. On the example of the organization of education in the camp in Aleksandrów Kujawski, a comparative analysis was made for other camps in Poland, where members of the UNR Army were stationed. The methodology of the research is based on the application of general historical methods of scientific research, namely: historical-comparative, typologization (historical-typological) and systematic analysis. An analysis of the peculiarities of the organization, methodological framework of the educational work of the interned military servants as part of the general cultural and educational activity of the Ukrainian interwar emigration is conducted for the first time, their effectiveness for obtaining higher education or the possibility of further professional activity outside the camp is also determined.
\end{abstract}

Keywords: UNR Army internment camp in Alexandrov Kuyavsky; military; cultural and educational activities; emigrant.

Introduction

The relevance of the topic is caused by the lack of its comprehensive and thorough research. Educational work has always been considered in the context of general cultural-educational activities. Therefore, it seems appropriate to analyze separately the organization and functioning of the system of educational institutions in Polish internment camps of the UNR Army. In addition, the interrelation between secondary education institutions and student communities in the camps should be emphasized, because the success of entrants when entering higher education institutes often depended on the well-functioning camp education system. Student communities were an integral part of the educational process in the camps. The coordinated cooperation between schools, student communities and the Ministry of National Education of the UNR made the educational process in the camps successful and made it possible for all wishing interned soldiers to fulfil their potential outside the camps, continuing their education as university students, gaining appropriate qualifications and specialties. Since previous studies of national and foreign scientists did not trace such a relationship and did not conduct a detailed analysis of all areas of the educational system in the camps of the interned UNR Army in Poland, it seems appropriate to emphasize this for the first time.

In addition, an analysis of the educational system and its effectiveness is conducted on the example of the camp in Aleksandrów Kujawski. In our opinion, this allows a comprehensive study of all aspects of educational activities in other camps where soldiers of the UNR Army stayed in Poland, taking into account the values of Aleksandrów Kujawski.

Some aspects of cultural-educational activity in the Ukrainian People's Army internment camps in Poland were raised in works by Z. Karpus (1996; 2002; 2008), E. Wiszka (2012), K. Paszkiewicz (1997: 329-334), A. Kolańczuk (2009), I. Sribnyak (2008: 65-76), O. Gumeniuk (2014); O. Humeniuk $(2016 ; 2017)$ and others. In general, researchers examined the general features and types of culturaleducational work in the camps of the interned UNR Army in Poland. However, a detailed analysis of the organization of education in camps, its quality and the importance for further admission and study at higher education institutions has not been made yet.

In addition, the article proposes to show student communities in the camps and their activities as an integral part of educational process of interned soldiers and of the whole interwar Ukrainian emigration.

The sources of the study include documents of the Central Military Archives in Warsaw (Centralny Archiwum Wojskowe w Warszawie), as well as documents of the Central State Archives of Supreme Authorities and Governments of Ukraine, Central State Archives of Public Organizations of Ukraine and Central State Archives of Foreign Ucrainica.

\section{Methods}

The methodology of the research is based on the application of general historical methods of scientific research, namely: historical-comparative, typologization (historicaltypological) and systematic analysis. Using the historicalcomparative method, the educational system of the UNR Army internment camps in Poland is explored. In particular, an analysis of the educational system and its effectiveness for the internees is conducted on the example of the camp in Aleksandrów Kujawski. This allows a comprehensive overview and comparison of all aspects of educational work in all the camps where members of the UNR Army were stationed in the early 1920s. 
The historical-typological method makes it possible to identify the reasons and methods of organizing educational activities in Aleksandrów Kujawski and in other internment camps of Ukrainians in Poland and also to trace the relationship between all educational institutions and determine the level of involvement of student communities in the overall cultural-educational process in camps. In addition, the historical-typological method allows to reconstruct the scheme of work of student communities and to determine the level of their effectiveness in support of the willing internees at admission to higher education institutions.

Using the systematic analysis method, all aspects of educational activities in camps can be explored and its importance for the cultural-educational sphere of Ukrainian interwar emigration in Europe can be determined.

\section{Results and Discussion}

One of the largest groups of emigrants in Poland, especially in the first half of the 1920s, were natives of the Dnieper Ukraine, namely, of the UNR Army soldiers interned in the camps. Events of the Polish-Soviet War were preconditions for the transition of the UNR Army to the Polish territory. According to the Treaty of Warsaw (April 21, 1920), Poland and the Ukrainian People's Republic allied in the war with Bolshevik Russia. The success of PolishUkrainian troops in spring - early summer of 1920 ended with a counter-attack by the Bolshevik troops. On the territory of the Right-Bank Ukraine in late summer - autumn 1920 the onslaught of Russian troops was deterred only by troops of the UNR Army. For a long time, the Ukrainians could not resist the overwhelming enemy forces and therefore were forced to cross the Zbruch River (border with Poland), after that its units were disarmed and interned in the camps: Aleksandrów Kujawski, Wadowice, Strzałkowo, Pikulice, Łańcut, Piotrków Trybunalski, Kalisz and Częstochowa ${ }^{1}$ (Karpus, 2008: 59; Karpus, 2002: 157).

Camp No. 6 in Aleksandrów Kujawski was established on December 8, 1920. In mid-December 1920, there were 900 officers (starshinas), 2504 Cossacks, 95 women and 29 children in camp ${ }^{2}$ (Karpus, 2008: 59). The largest group consisted of soldiers of the 4th Kyiv and 6th Sich Riflemen divisions and other units, although it was intended for the reception of no more than 3000 people $^{3}$. And the conditions in the camp were not the best: cold barracks and often insanitariness ${ }^{4}$

However, despite the difficult physical and moral conditions of the interned soldiers, cultural-educational work was unfolding in the camp. The senior leadership of the UNR Army and Supreme Commander, Symon Petliura himself, repeatedly emphasized the importance of culturaleducational activities for the military servants. Thus, in one of his speeches, he stated: "... all of us, from Cossacks to the highest Starshinas, must learn and learn. We need to be ready to create a new big and strong Ukraine on the ruins of the country. It is necessary for us to return to our native land being educated, cultured citizens, prepared for hard work - state building. Train, set up officer and subofficer schools, courses, illiterate schools, specialist schools and courses. No illiterate person should return to Ukraine"5 (Paszkiewicz, 1997: 330).

Therefore, in order to achieve the goals, a culturaleducational program of activities in the camps was developed, which included a number of activities: organization

\footnotetext{
1 The Central Military Archives (CAW), Sprzymierzona Armia Ukraińska, $380.1 / 50$, s. 3

${ }^{2}$ CAW, Sprzymierzona Armia Ukraińska, 380.1/50, s. 3, 14

3 lbid

4 lbid, s. 3

5 lbid, s. 58 .
}

of artistic groups, artistic societies etc., as well as systematic conduct of educational work at schools of different levels - elementary, secondary, gymnasiums; organization of Ukrainian studies courses and foreign language courses (Polish, English, German, French, Esperanto) ${ }^{6}$. It was important to prevent the soldiers in internment from losing martial spirit, so the camps conducted cultural-educational work that helped to support and disseminate nationalpatriotic ideas ${ }^{7}$.

It should be noted that talking about cultural-educational work in general, we emphasize the educational direction, because we are seeking to analyze the system of educational institutions for the internees, methods of work and to determine their level of effectiveness in terms of accomplishing the tasks. The practical implementation of the tasks was entrusted to the cultural-educational departments established under the headquarters of the relevant divisions ${ }^{8}$. Soon enough (during the first winter months of 1921), they started taking actions in almost all brigades, regiments, sotnyas and kurens, in particular, of the 4th and 6th divisions of the UNR Army, interned in the camp in Aleksandrów Kujawski ${ }^{9}$ (Sribnyak, 2008: 66-67). The cultural-educational department of the camp consisted of the head of the department, two of his assistants, one clerk and one parcel shooter. Sotnik Hladkyy was appointed a chief of such department in Aleksandrów Kujawski by order of March 17, $1921^{10}$.

Increasing the educational level of the military servants was one of the priority tasks. There was a significant number of illiterate and uneducated people, at the beginning of 1921 there were 947 such people at the camp in Aleksandrów Kujawski (Karpus, 2008: 61) In total, there were also 1303 people with primary education, 657 with secondary education and 18 with higher education ${ }^{11}$ (Wiszka, 2012: 247)

Thus, schools for the illiterate and uneducated people were primarily established in the camps. Assistance in their founding was provided by the Young Men's Christian Association (YMCA) ${ }^{12}$. In addition, lectures on the history and geography of Ukraine were initiated, as well as studying of foreign languages and lessons on military discipline were conducted for officers. Such forms of activity were typical for of all UNR Army internment camps, most actively they were conducted in camps in Pikulice, Aleksandrów Kujawski and Łańcut (Karpus, 1996: 458-459).

The congress of representatives of cultural-educational organizations in the Army on March 20 and 21, 1921 in Łańcut contributed to the standartization and intensification of cultural-educational work in the camps. In general, the congress participants considered the current state of cultural-educational work in the field and stated its positive and negative sides, as well as considered and approved a detailed plan of cultural-educational work in the UNR Army $^{13}$ (Gumeniuk, 2014: 119-121).

The following provisions were accepted for implementation at the congress:

${ }^{6}$ CAW, Sprzymierzona Armia Ukraińska, 380.1/50, s. 67; The Central State Archives of Higher Bodies of Government and Administration of Ukraine (CSASA of Ukraine) fond 2439, List 1, file 33. p. 20.

7 CAW, Sprzymierzona Armia Ukraińska, 380.3/204, s. 126-127; CSASA of Ukraine, fond 2439, List 1, file 33. p. 2.

${ }^{8}$ CSASA of Ukraine, fond 3526, list 1, file 3. p. 2.

9 lbid, list 1, file 1. p. 7-8.

$10 \mathrm{lbid}$, fond 2439, list 1, file 33. p. 59.

11 lbid, fond 1075, list 2, file 197. p. 4.

12 CAW, Sprzymierzona Armia Ukraińska, 380.1/55, s. 52-53.

13 The Central State Archive of Foreign Ucrainica (CSAFU), fond 15 , list 1 , file 71 . p. 94. 
- establishing of a permanent and special unit of cultural-educational workers of the army as a separate professional service;

- rise of the role of cultural-national education of the army to the level of professional military education;

- formation of separate cadres of cultural-educational advisers and instructors (divisional, kuren and sotnya) at military units;

- establishment of elementary, secondary and apprentice schools in the army, where Cossacks and Starshinas with incomplete education could continue it;

- camps provide courses for school programs. Courses are served by teaching staff of a particular camp. The Ministry of National Education of the UNR provides assistance in this regard: materials and human resources;

- education is provided by a rehearsal system that give more opportunities for individual student learning. The rehearsal system will also provide an opportunity for more people to participate in the educational work. After completion, students will receive official certificates ${ }^{14}$ (Gumeniuk, 2014: 121).

The coordination commission consisting of three people implemented the decisions taken (Kolańczuk, 2009: 47).

It should be noted that the decisions taken at the congress had a positive impact on the organization of education in camps. They made it possible to create a unified system of schools in camps and improve the quality of education. Thus, in Aleksandrów Kujawski, similar to other camps, in spring of 1921 literacy schools achieved the status of the I degree (grade) of the Unified State School, the lower elementary schools - the II degree and the higher elementary schools - the III degree. Further education of soldiers was conducted at higher levels (from IV to IX). Graduation from the last grade made it possible to receive secondary education ${ }^{15}$ (Wiszka, 2012: 249; Sribnyak, 2008: 68). Thus, in the 6th division, four schools were founded (150 Cossacks were studying) and operated until May 1921. Further education continued in the general divisional school, created on the model of the Unified State School. 73 people studied there ${ }^{16}$.

The Young Men's Christian Association (YMCA), previously mentioned, joined the establishing of the Real school in the camp in Aleksandrów Kujawski. Thanks to it, the Starshinas and Cossacks of the 4th and 6th divisions completed their secondary education and prepared properly for admission to higher education institutions (Bytynskyy, 1932: 37).

The educational system at Aleksandrów Kujawski and other camps was organized in such a way as to accomplish two main tasks: to solve the problem of illiterate or uneducated soldiers and to prepare secondary school graduates for higher education. In this article, we deliberately avoid the question of military-professional education for internees because this question deserves separate thorough research. So, the first task in Aleksandrów Kujawski was successfully fulfilled. Thus, at the time of dismantling of the camp at the end of autumn of 1921, a small percentage of the soldiers remained illiterate (Sribnyak, 2008: 69). The second task was more relevant in the middle of 1921 , when student communities in the camps took a prominent place in the educational system of internees and helped their members to obtain the necessary knowledge, certificates of completion of secondary education and prepare

\footnotetext{
${ }_{14}$ CSAFU, fond 15, list 1, file 71. p. 56; CAW, Sprzymierzona Armia Ukraińska, 380.1/59, s. 21.

15 CAW, Sprzymierzona Armia Ukraińska, 380.1/59, s. 21.

${ }^{16}$ CSASA of Ukraine, fond 1075 , list 1, file 544. p. 31.
}

for admission to higher education institutions (Humeniuk, 2017: 34; 2016: 9).

In Aleksandrów Kujawski, the student community was founded in spring of 1921 and united 50 members of the divisional student communities. Its main tasks included involvement in the cultural-educational work of the camp, assistance to its members in admission to higher education institutions etc. ${ }^{17}$ (Wiszka, 2012: 250-251). It is interesting that the first mentions of the students here were dated March 14, 1921, when in the Order to the UNR Army Group of Interned Forces in camp No. 6 unit 32 there was information about those students who wanted to continue their education outside the camp at Lviv University. They were required to provide registration cards with information about their educational background ${ }^{18}$. In addition, Polish and German language courses were organized in the camp by the Student Community (Wiszka, 2012: 250-251). In total, at the end of 1921 the number of members of the student communities in the internment camps of the UNR Army in Poland was over 1 thousand ${ }^{19}$.

It can be argued that with the formation of student communities, especially in internment camps, the student movement was institutionalized. Important steps in this direction were the congresses of representatives of the student communities, that took place during 1921-1922 (five congresses were held).

In order to develop the main provisions of academic work in Poland, its forms and methods, and to establish a governing representative body, a congress of representatives of all student communities was held in Warsaw on June 20-23, 1921. The Union of Ukrainian Student Communities in Poland was established there and the General Authority of the Union was elected ${ }^{20}$.

One of the main tasks of the first congress of student communities was to requalify former military officers who wanted to pursue higher education as soon as possible and promote their release of internment. The main direction of work involved the admission of as many members as possible to student communities, their further requalification and the provision of the necessary documents (often certificates of education) to those who did not have them for different reasons ${ }^{21}$

At the end of August 1921, the second congress of representatives of the student communities was convened in Warsaw. It elected a new composition of the General Authority and entrusted it to remove barriers to students' admission to higher education institutions effectively. Thus, in particular, the General Authority, on behalf of the congress representatives, succeeded in canceling the order of the UNR Military Ministry on the prohibition of leaves for military servants for continuing education ${ }^{22}$.

Such measures became possible on the appeal of the Ukrainian Liquidation Commission to the Polish authorities. Students from internment camps were provided with leaves (up to 22 months) for admission to higher education institutions. Such vacations could be continued if a person did not manage to admit high school or go abroad. The leave was canceled if the student was unable or unwilling to enter the higher education institution within the specified period. In that case, he returned to the internment position ${ }^{23}$.

\footnotetext{
17 CAW, Sprzymierzona Armia Ukraińska, 380.1/50, s. 67.

${ }^{18}$ CSASA of Ukraine, fond 2439, list 1, file 33. p. 76.

${ }^{19}$ CSAFU, fond 15 , list 1, file 71. p. 96

20 The Central State Archive of Public Associations of Ukraine (CSAPA of Ukraine), fond 269, list 1, file 517. p. 110.

21 lbid, List 1, file 517. p. 120.

$22 \mathrm{lbid}$, fond 269 , list 1, file 517. p. 120

${ }^{23}$ CSASA of Ukraine, fond 3570 , list 1 , file 14. p. 13.
} 
During the leaves, financial aid was envisaged for those military students who sought to enter higher education institutions. However, sometimes there were difficulties in obtaining such aid. The amount for military students who were released on leave to complete their education was estimated at 25,000, 20,000, 15,000 Polish marks (hereinafter referred to as MP) ${ }^{24}$ (the total amount at the time of leave for admission to higher education institution). Thus, according to other data, in 1922, there were 360 UNR Army students, and the UNR Government received a request for monthly payments of 8,000 MP to such students to enable them to enter higher education institutions ${ }^{25}$. Taking into the account the limited resources of funds, the Government of the UNR could not always fully satisfy all requests and provide funds to all wishing soldiers at the time of their admission to higher education institutions ${ }^{26}$.

Most students from the former soldiers did not have any original documents about education. This, in turn, could have made it difficult for them to enter Polish higher education institutions. Therefore, the Ministry of National Education of the UNR collected information about the educational level of each student and issued certificates based on these data and documents. The certificates contained information about a completed secondary school or a high school where the student was enrolled, but exam grades were not indicated. Thus, those Ukrainian students who did not have the original maturus (certificate of secondary education) were deprived of the opportunity to enter, for example, the Higher Trade School in Warsaw, where there was a competition of certificates, and especially in the case when foreigners tried to enter there without originals of certificates of secondary education ${ }^{27}$.

The decisions of the second congress testified that the student action had real ground, students constituted a significant part of all emigrants. After the congress, the active phase of so-called "inscription" action began, i.e. submission of documents for admission to higher education institutions.

In December 1921, the third congress of representatives of student communities was convened in Warsaw. At the congress, the highest attention was paid to the admission of former military officers to higher education institutes, respectively, stated that the number of student communities in the camps had decreased. It was stated that there were practically no reasons that would require a further stay of students in camps, and delayed their departure from the camps because of their inertia and lack of corresponding facilities ${ }^{28}$.

The fourth congress of student communities' representatives was held from April 29 to May 5, 1922. The issues raised by the congress concerned all spheres of Ukrainian student emigration. In particular, it was emphasized that the camp communities, as transitional organizations, had already had sufficient time to provide the move of all their members to academic centers, and that the congress decided that by the following academic year these organizations had to be completely eliminated by transferring their members to direct academic work ${ }^{29}$. In general, active work of student communities in the camps was conducted during 1921-1922. During this time, all internees who wanted to enter higher education institutions did so. Thereby, student communities in the camps fulfilled

\footnotetext{
24 Ibid, file 13. p. 114.

25 Ibid, file 13. p. 166

26 lbid, p. 59

27 Ibid, file 32. p. 204

${ }^{28}$ CSAPA of Ukraine, fond 269, list 1, file 517. p. 125.

29 Ibid, p. 136
}

their primary task: to allow their members to improve their cultural-educational level, obtain necessary education in the camp schools and then help them join the ranks of students of universities in Poland and other European countries.

\section{Conclusions}

The organization of education in the camp in Aleksandrów Kujawski, as well as in other places of internment of the UNR Army soldiers was conducted at a rather high level. The level of education of all the soldiers in the camp was primarily determined. This was done to make full use of the potential of the military servants and to organize the most effective educational process. From the very beginning of the internment, schools for illiterate and uneducated Cossacks were established in Aleksandrów Kujawski (December 1920). When the camp was eliminated at the end of the autumn of 1921 , it became apparent that the problem of illiteracy was eliminated too.

During the research it was found that cultural-educational work in the camps became more active and systematic after the congress of representatives of the culturaleducational departments on March 20-21, 1921. After the congress, educational activities became systematic and balanced. The Ministry of National Education of the UNR joined the development of educational programs and provided various assistance in the field. In addition, schools of various degrees of the Unified State School enabled their students to improve their level of knowledge quickly and effectively, and graduates of the last degrees (grades) received certificates of completed secondary education, which allowed them to enter higher education institutions.

The level of involvement of student communities in the educational process in the camps has been identified. Cooperation between schools, student communities, the Ministry of National Education of the UNR was analyzed. Such coordinated interaction made the educational process in the camps successful and gave opportunity to all willing internees to continue their education in higher education institutions. Student communities took care of raising the educational level of their members and overcoming all difficulties from certificates of secondary education to the organization of paid leaves for the military servants during the university admissions process. The effective work of student communities was highlighted at the first such congresses in the early 1920s.

On the basis of a wide range of archival documents and previous scientific research, the organization and conducting of educational work in the camp of UNR Army internment in Aleksandrów Kujawski was thoroughly analyzed. A general scheme of educational activity in the internment camps of the UNR Army was reproduced on the example of Aleksandrów Kujawski. It was determined that due to the effective use of human potential (in view of the educational level of soldiers) and the systematic approach to the educational process in the camps, it was possible to organize the educational process and to ensure a rapid transition of military servants to the ranks of students in cooperation with student communities.

\section{REFERENCES}

Bytynskyy, M. (1932). Ukrayinske voyatstvo na kulturno-osvitniomu fronti. Hurtuymosya. Praha, ch. 9, s. 37. (In Ukrainian)

Gumeniuk, O. (2014). Kulturalno-oświatowa działalność w obozach internowanych w Polsce w kontekście ukraińskiej studenckiej emigracji. Historia i Polityka. No 11 (18): 117-124. (In Polish)

Humeniuk, O. (2016). Shlyakh emihranta: vid voyina do studenta. Nashe slovo, № 7. P.9 (In Ukrainian)

Humeniuk, O. (2017). Ukrayinski molodizhni orhanizatsiyi v 
Polshchi: typolohizatsiya i formy diyalnosti (1920-1939). Nad Wisł a i Dnieprem. Polska i Ukraina w przestrzeni eurazijskiej - przeszł ość i teraźniejszość. Toruń-Saragossa: International Association of Historians and Archives, Vol. 1: 33-40. (In Ukrainian)

Karpus, Z. (1996). Pobyt żołnierzy Ukraińskiej Republiki Ludowej w obozach internowania w Polsce w latach 1920-1924. Europa Orientalis. Polska i jej wschodni sąsiedzi od średniowiecza po wshół czesność. Toruń: 455-464. (In Polish)

Karpus, Z. (2002). Jeńcy i internowani rosyjscy i ukraińscy na terenie Polski w latach 1918-1924. Toruń: 209 p. (In Polish)

Karpus, Z. (2008). Obozy uchodźców, jeńców i internowanych w Aleksandrowie Kujawskim 1918-1921. In: Aleksandrów Kujawski. Obozy jeńców i internowanych 1918 - 1921. Toruń: 51-64. (In Polish)

Kolańczuk, A. (2009). Ukraińscy generał owie w Polsce. Emigranci polityczni w latach 1920-1939. Przemyśl, 283 s. (In Polish)

Paszkiewicz, K. (1997). Szkolnictwo i oświata wojsk Ukraińskiej Republiki Ludowej internowanych w Polsce w latach 19201924. Polska i Ukraina. Sojusz 1920 roku i jego następstwa. Toruń: 329-334. (In Polish)

Sribnyak, I. (2008). Kulturno-osvitnya robota $v$ tabori internovanykh viysk UNR. Aleksandriv Kuyavskyy u 1920-1921 rr. In: Aleksandrów Kujawski. Obozy jeńców i internowanych 1918-1921. Toruń: 65-76. (In Ukrainian)

Wiszka, E. (2012). Szósta Siczowa Dywizja Strzelecka Armii Ukraińskiej Republiki Ludowej. Toruń, 513 s. (In Polish)

\section{LIST OF REFERENCE LINKS}

Битинський М. Українське вояцтво на культурно-освітньому фронті. Гуртуймося. Прага, 1932, ч. 9, с. 37.
Гуменюк О. Українські молодіжні організації в Польщі: типологізація і форми діяльності (1920 - 1939). Nad Wisł ą i Dnieprem. Polska i Ukraina w przestrzeni eurazijskiej - przeszł ość i teraźniejszość. Toruń-Saragossa: International Association of Historians and Archives, 2017. Том 1. C. 33-40.

Гуменюк О. Шлях емігранта: від воїна до студента. Наше слово. Варшава, 2016, № 7, с. 9.

Срібняк І. Культурно-освітня робота в таборі інтернованих військ УНР Александрів Куявський у 1920 - 1921 pp. Aleksandrów Kujawski. Obozy jeńców i internowanych 1918-1921. Toruń, 2008. C. 65-76.

Gumeniuk O. Kulturalno-oświatowa działalność w obozach internowanych w Polsce w kontekście ukraińskiej studenckiej emigracji. Historia i Polityka. 2014. No 11 (18): 117-124.

Karpus Z. Jeńcy i internowani rosyjscy i ukraińscy na terenie Polski w latach 1918-1924. Toruń, 2002. 209 p.

Karpus Z. Obozy uchodźców, jeńców i internowanych w Aleksandrowie Kujawskim 1918-1921. Aleksandrów Kujawski. Obozy jeńców i internowanych 1918 - 1921. Toruń, 2008. 51-64.

Karpus Z. Pobyt żołnierzy Ukraińskiej Republiki Ludowej w obozach internowania w Polsce w latach 1920-1924. Europa Orientalis. Polska i jej wschodni sąsiedzi od średniowiecza po wshół czesność. Toruń, 1996. 455-464.

Kolańczuk A. Ukraińscy generałowie w Polsce. Emigranci polityczni w latach 1920-1939. Przemyśl, 2009. $283 \mathrm{~s}$.

Paszkiewicz K. Szkolnictwo i oświata wojsk Ukraińskiej Republiki Ludowej internowanych w Polsce w latach 1920-1924. Polska i Ukraina. Sojusz 1920 roku i jego następstwa. Toruń, 1997. S. 329-334.

Wiszka E. Szósta Siczowa Dywizja Strzelecka Armii Ukraińskiej Republiki Ludowej. Toruń, 2012. 513 s.

Збігнєв Карпус,

Університет Миколая Коперника (м. Торунь, Польща)

e-mail: zk@umk.pl, ORCID 0000-0001-5018-976X

Олена Гуменюк,

Київський університет імені Бориса Грінченка (м. Київ, Україна)

e-mail: o.gumeniuk85@gmail.com,ORCID0000-0003-0497-6767

\section{ОСВІТА ІНТЕРНОВАНИХ ВІЙСЬКОВИХ АРМІї УНР В ПОЛЬЩІ: НА ПРИКЛАДІ ТАБОРУ В АЛЕКСАНДРОВІ КУЯВСЬКОМУ}

Мета роботи передбачає аналіз освітньої діяльності - системи організації та ї̈ напрямків, характерних для військових Армії Української Народної Республіки (УНР), інтернованих в таборах Польщі на початку 1920-х років. На прикладі організації освіти в таборі в Александрові Куявському зроблено порівняльний зріз і для інших таборів в Польщі, де були розміщені військові Армії УНР. Методологія дослідження ґрунтується на застосуванні загальноісторичних методів наукового дослідження, а саме: історико-порівняльного, типологізації (історико-типологічний) та системного аналізу. Вперше проводиться аналіз особливостей організації, методологічних засад освітньої роботи інтернованих військових як частини загальної культурно-освітньої діяльності української міжвоєнної еміграції, а також визначається їх ефективність для здобуття вищої освіти або ж з можливістю подальшої професійної діяльності поза межами табору. У результаті проведеного дослідження було встановлено, що культурно-освітня робота в таборах пожвавилась та набула системного характеру після з'їзду представників культурно-освітніх відділів 20-21 березня 1921 р. Зокрема освітні програми почали розроблятися під керівництвом Міністерства народної освіти УНР; Єдиною Державною Школою, окрім практичної освітньої допомоги, видавались сертифікати про закінчену середню освіту, що дозволяли вступати до вишів випускникам останніх ступенів (класів). На прикладі освітньої роботи в таборі інтернованих військових Армії УНР в Александрові Куявському показано, що злагоджена взаємодія шкіл, студентських громад та Міністерства народної освіти УНР підвищувала успішність освітнього процесу і забезпечувала швидкий перехід військових до лав студентства.

Ключові слова: табір інтернованих військових Армії УНР в Александрові Куявському; військовий; культурно-освітня діяльність; емігрант.

(c) Zbigniew Karpus, Olena Humeniuk

Надійшла до редакції: 04.11.2019

Прийнята до друку: 21.11.2019

ISSN 1728-9343 (Print)

ISSN 2411-3093 (Online) 